\title{
Deterioro selectivo de las areniscas en las catedrales de Salamanca. La anisotropía textural como factor del mismo
}

\author{
Selective sandstone deterioration in the cathedrals of \\ Salamanca. Textural anisotropy as a cause
}

\begin{abstract}
RESUMEN
La anisotropia textural de las areniscas se relaciona con la selectividad de su deterioro en los edificios.

Las muestras estudiadas pertenecen a las Catedrales de Salamanca.

Fragmentos de piedra, cortados en direcciones diferentes respecto a la base sobre la que se asientan los sillares en el muro, son estudiados por medio de la lupa binocular y del microscopio electrónico de barrido (SEM).
\end{abstract}

De éstos se deduce que la microfábrica de las areniscas tiene una microtextura granular y otra laminar, que corresponden a direcciones diferentes del plano respecto al asiento del sillar. Una u otra de estas situaciones coincide con la superficie de la piedra expuesta al exterior en el edificio, y afectan a su deterioro superficial de forma diferente. Las capas externas en las que predomina la arcilla tienen menos resistencia a los agentes de alteración.

Las imágenes del SEM de los cortes en piedras deterioradas se compararon con los de piedras no deterioradas, y ambos en direcciones diferentes respecto al asiento del sillar, deduciendo que la posición dada al bloque de piedra en el edificio es importante para su conservación.

La velocidad de transmisión de ultrasonidos, medida en muestras de cantera comercial, confirma la anisotropia textural de las areniscas, en mayor o menor grado.
$M^{a}$ TERESA MARTÍN PATINO* ${ }^{\star}$ FERNANDO MADRUGA ${ }^{* *}$, JULIO SAAVEDRA***

ESPAÑA

\author{
ABSTRACT \\ Textural sandstone anisotropy is related to the selective \\ deterioration of such stone in buildings. \\ The samples studied come from the (athedrals of Salamanca. \\ Stone fragments, cut in different directions with regard to the \\ base supporting the ashlars in the wall, are studied by means \\ of a binocular magnifying glass and the Scanning Electron \\ Microscopy (SEM).
}

This shows that the sandstone microfabric has a granular and a laminar microtexture, which correspond to different directions in the plane in question as regards the position of the ashlar.

Lither of these circumstances coincide with the stone surface on the outside of the building and affect its surface deterioration in a different way.

\begin{abstract}
The SEM images of deteriorated stone were compared with those of unaffected stone, with both types coming from differently orientated cuts as regards the position of the ashlar. In conclusion, the position given to the block of stone in the building is of importance for the preservation of the stone.
\end{abstract}

The speed of ultrasound transmission measured in samples from commercial quarries confirms the textural sandstone anisotropy to a greater or lesser extent.

\section{INTRODUCCIÓN}

El conjunto arquitectónico de las Catedrales de Salamanca fue el monumento elegido por un grupo de investigadores para realizar un Proyecto de

\section{INTRODUCTION}

The architectural complex of the Cathedrals of Salamanca was the site chosen by a group of researchers to carry out a research project about

* CSIC y Universidad Autónoma de Madrid

** Euroconsult, Salamanca

*** CSIC, Salamanca 
Investigación sobre la arenisca de Villamayor como material de construcción. Los criterios que se siguieron al tomar las muestras a estudiar han sido ya expuestos (1). Reincidiendo, el motivo principal fue establecer comparaciones entre unos sillares, superficialmente deteriorados, y otros contiguos bien conservados, figura 1. Este deterioro selectivo puede contemplarse repetidamente en los edificios de la ciudad.

Las propiedades fisico-mecánicas, mineralógicas y granulométricas de estas piedras, presentadas en publicaciones anteriores (1) y (2), demuestran que todas sus características son semejantes, no encontrando, en aquel momento, el factor que determina la selectividad en su degradación.

Diferentes investigadores han estudiado el problema del deterioro en la arenisca de Villamayor, y atribuyen su origen principal al exceso de humedad en sus diferentes formas y efectos (3), (4), (5), (6), (7), (8), (9) y (10). Sin embargo, no se ha insistido convenientemente en que, aparte de situaciones muy concretas de humedad intensa y constante, el hecho del deterioro de tal piedra se encuentra en bloques aislados, mientras los edificios en general están sorprendentemente bien preservados.

La alteración en la piedra está vinculada con la velocidad de absorción de agua y el proceso posterior de secado por evaporación. Amoroso y Fasina (11) indican que la evaporación desde la superficie de un material poroso está determinada por factores externos, tales como las condiciones ambientales, así como por factores internos, tales como el movimiento del agua en el interior de la piedra hasta llegar a la superficie. En cuanto a los primeros: temperatura, humedad relativa de la atmósfera y velocidad de circulación del aire, afectan por igual a las piedras que ocupan posiciones semejantes en el muro. Los factores internos responden a la estructura de la piedra, término que describe el efecto combinado de fábrica, composición y fuerzas entre partículas. Esta estructura puede tener un cierto

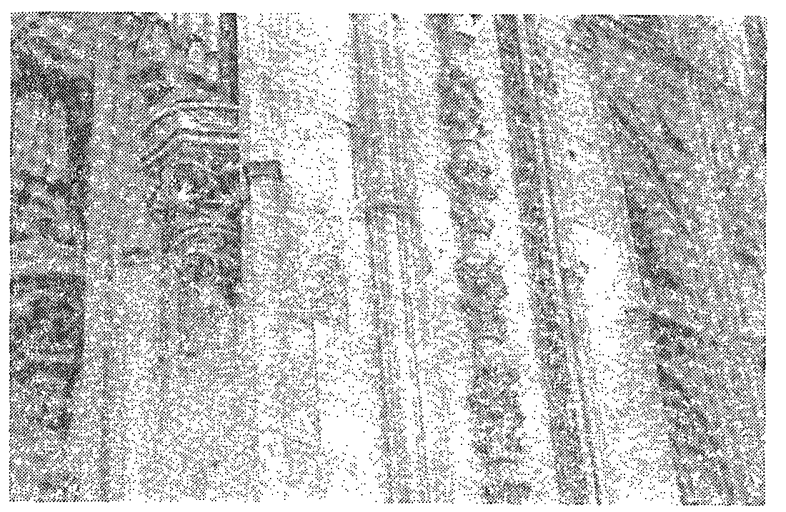

Villamayor sandstone. The criteria established for sample taking have already been described (I). Again the main reason was to establish a comparison between ashlars with a deteriorated surface and well-preserved others nearby, figure 1. Such selective deterioration can be observed repeatedly in the buildings of the city.

The physico-mechanical, mineralogical and granulometric properties of these stones, described in earlier publications, (1) y (2), prove that all their characteristics are similar. At that point the factor determining selective deterioration was not found.

Different researchers have studied the deterioration problem of Villamayor sandstone, (1), (2), (3), (4), (5), (6), (7), (8), (9) y (10). According to them,

the main cause is excessive humidity in its different forms and effects. Apart from very concrete situations of intense and constant humidity, however, the fact that the deterioration of such stone is found in isolated blocks has not been taken into account sufficiently, while the buildings in general are surprisingly well preserved.

The alteration in the stone are connected with the speed at which the water is absorbed and with the drying process through evaporation. Amoroso and Fasina (11) point out that the evaporation from the surface of porose material is determined by external factors, such as environmental conditions, as well as by internal factors, such as the movement of the water inside the stone on its way to the surface. As regards the former, the temperature, relative humidity of the atmosphere and the speed of circulating air have the same influence on the stones with similar positions in the wall. The internal factors are due to the structure of the stone, a term describing the combined effect of the fabric, composition and forces among the particles. Such a structure may have a certain degree of

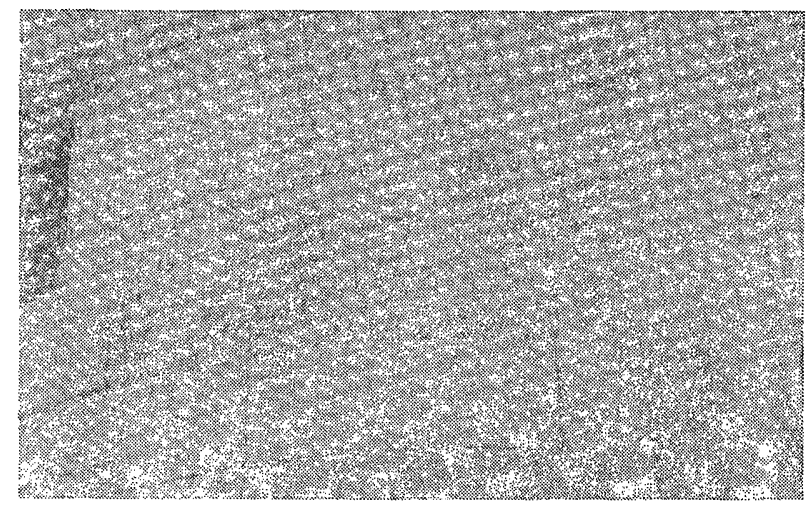

Fig 1.- Detalle del deterioro selectivo en fachadas de las Catedrales. 
grado de anisotropía. Si tal es el caso, el comportamiento de la piedra estará condicionado por su asentamiento en el edificio.

\section{SITUACIÓN DE LAS MUESTRAS Y MÉTODO DE ESTUDIO}

Las muestras pertenecen a áreas diferentes de ambas Catedrales de Salamanca: al muro de la fachada norte y muro de la fachada sur de la Catedral Vieja, en el nivel primero; al muro de la fachada de poniente de la Catedral Nueva, en el nivel segundo; al muro interior de entrada a la Torre, y al muro interior de la escalera. En cada una de estas áreas se eligieron dos sillares contiguos o muy cercanos, uno deteriorado y otro sin deterioro superficial visible, de los que se sacaron testigos mediante sonda de rotación. El estudio se hizo sobre fractura fresca en fragmentos de piedra cortados de cada testigo en dos direcciones diferentes; un corte era hecho paralelo a la base sobre la que está asentado el sillar, mientras el otro corte era vertical a la base. Los canteros tienden a colocar los sillares coincidiendo con el lecho o estrato, es decir, sobre la superficie perpendicular a la dirección de compactación del sedimento. La expresión utilizada es "asentar la piedra a lecho". Sin embargo, algunas veces se encuentran sillares en disposición diferente.

Las secciones, o cortes, paralelos a la base del sillar, coinciden con el estrato cuando el sillar está asentado a lecho, y quedan verticales a él cuando la posición de la piedra es diferente.

Las muestras se observaron por medio de la lupa binocular, y a continuación se estudiaron detenidamente en el microscopio electrónico de barrido (SEM). El microanálisis por energía dispersiva de rayos-X $(E D A X)$ se utilizó para identificar la composición de las partículas.

La velocidad de transmisión de ultrasonidos fue medida sobre los tres ejes de bloques prismáticos en 36 muestras de cantera comercial. No se han realizado medidas sobre las muestras del monumento por no disponer de piezas con las dimensiones requeridas para el caso.

\section{ANÁLISIS MICROSCÓPICO DE LA PETROFÁBRICA}

Las superficies de fractura de cada piedra, observadas en la lupa binocular, manifiestan aspectos microtexturales diferentes. Láminas de arcilla dominan en uno, y granos de arena en el otro. Estas diferencias anisotropy. If that is the case, the behaviour of the stone will be conditioned by its assent in the building.

\section{SITUATION OF THE SAMPLES AND THE RESEARCH METHOD}

The samples come from different areas of both Cathedrals of Salamanca: the wall of the southern façade of the Vieja Cathedral at the first level, the wall of the western façade of the Nueva Cathedral at the second level, the inside wall of the entrance to the tower and the inside wall of the stairs. In all these areas two neighbouring or nearby ashlars were chosen, a deteriorated block and another without visible surface deterioration. Samples were taken from all of them with the help of a rotation drill. The study was based on the fresh fractures of stone fragments cut in two different directions from every sample. One cut was made parallel to the base supporting the block of stone, while the other cut was vertical to the base. The stonemasons tend to place the ashlars so as to coincide with the layer, ie, on the surface perpendicular to the direction of sediment compactation. The expression used is that of "placing the stone according to the layer". However, sometimes the ashlars are found in other positions.

The cuts parallel to the base of the ashlar coincide with the stratum when the block of stone has been placed according to the layer. They are vertical to the layer when the position of the stone is different.

The samples were first studied by means of a binocular magnifying glass. After that they were carefully studied by using a SEM. EDAX was used to identify particle composition.

Ultrasound transmission speed was measured along three axes of prismatic blocks in 36 samples of the commercial quarry. Measurements of the samples from the monument were not taken since there were no samples of the size required in this case.

\section{MICROSCOPIC ANALYSIS OF THE STONE FABRIC}

Under the binocular magnifying glass, the texture of the fracture surfaces of every stone was different. Clay laminas dominated in some and sand grains in others. These differences are found when the direction of the 
se aprecian ćuando la orientación de la fractura respecto al asiento del sillar es también diferente, es decir, corresponden a planos paralelos o verticales a dicho asiento.

De acuerdo con las imágenes observadas en el SEM, la microfábrica de estas areniscas está constituida por granos de arena y partículas de arcilla en contacto tangencial. Cada grano de arena queda perfectamente recubierto por una capa fina de arcilla que mantiene la unión entre los mismos. Este ordenamiento de las partículas presenta aspectos microtexturales diferentes, como se ha indicado, dependiendo de la orientación del plano en observación. En los planos verticales al lecho del sedimento, cada grano de arena queda bordeado por los agregados arcillosos, asemejando las paredes de la celdilla que lo contiene. En los planos que coinciden con el lecho, dominan las arcillas recubriendo los granos de arena. Las figuras 2 ( $a$ y b), dos cortes diferentes de una muestra, exponen, respectivamente, las dos microtexturas descritas. En la parte superior de la imagen a), se aprecia el hueco que dejó uno de los granos al desprenderse. En la imagen b), las láminas de arcilla tienen formas cóncavas, consecuencia de la disposición de los granos de arena depositados sobre ellas. Estos granos se han desprendidos posteriormente al quedar expuestos al exterior. La anisotropía en la textura de las areniscas puede ser deducida de estas observaciones.

Cada uno de estos aspectos de la microtextura corresponden a caras determinadas de los sillares situados en una fachada. Así, los sillares asentados a lecho, tienen caras que coinciden o están más próximas a los planos verticales a la base sobre la que se asientan, en las que predominará la microtextura granular, y la microtextura laminar arcillosa en las caras que coinciden con la base. De forma análoga, los sillares no asentados a lecho, tienen dos caras verticales a la base y que coinciden con el plano del estrato en cantera, en las que dominará la microtextura laminar, en las otras caras dominará la microtextura granular. En las areniscas, salvo algunas excepciones, no es perceptible a la vista una estratificación que permita determinar sus posiciones. Solamente la pericia de los canteros o un análisis microscópico pueden diferenciarlas.

Las consecuencias respecto al deterioro superficial de la piedra son obvias. La resistencia de la capa superficial, expuesta a los agentes externos de alteración, será menor cuando en ella predomine la arcilla, la cual se desintegra más facilmente, que cuando la forman granos de arena íntimamente unidos. Las arcillas tienen mayor capacidad de absorción y retención del agua, especialmente cuando esmectitas y paligorsquitas están entre los componentes arcillosos de la piedra, fracture as regards the placing of the ashlar is also different, ie, they appear when the planes run parallel or vertical to the placing.

According to the SEM images, the microfabric of such sandstone consists of sand grains and clay particles in tangential contact. Each grain of sand is coated perfectly by a fine layer of clay which keeps them together. This order of the particles, has microtexturally different aspects, as has been pointed out, depending on the planes studied. In the planes that are vertical as regards the sediment stratum, every grain of sand is bordered by clay aggregates, which look like the walls of the little cell surrounding the grain. In the planes that coincide with the stratum it is mainly clay coating the grains of sand. Figures 2( $a$ and $b$ ), ie, two different cuts of the same sample, respectively show the two microtextures described. In the upper part of picture (a), there is an empty space left by one of the grains when it fell out. In picture (b), the clay laminae have concave forms, which is a consequence of the disposition of the sand grains deposited on them. These grains fell out when they were exposed to the outside. Structural sandstone anisotropy can be deduced from these observations.

Each of these microtextural aspects corresponds to specific sides of the ashlar in a façade. Thus, in the ashlars placed in accordance with the stratum, the sides which coincide with the vertical planes regarding the base by which they are supported, have a granular microtexture, while a laminar clay microtexture is found in the sides in line with the base. In the same way, in the ashlars placed in other positions, the sides in line with the base and two vertical sides have a dominant granular microtexture, while the other vertical sides in line with the quarry stratum their microtexture is laminar. Apart from a few exceptions, a stratification, which would help to determine the sandstone layout, is not visible. A stonemason 's skill alone or a microscopic analysis may distinguish between them.

The consequences as regards the durability of the stone is obvious. The resistance of the surface layer, exposed to external weathering agents, is lower when clay predominates, which disintegrates more easily than in the presence of closely linked sand grains. Clays have a greater absorption and water retention capacity, especially when smectites and paligorskites are among the clay components of the stone, as is the 
como es el caso de estas areniscas, trabajo ya citado. En tal caso hay una pérdida del material cementante produciendo la arenización de la piedra.

Después de comparar las imagenes obtenidas por SEM en muestras de piedra deteriorada con las de piedra no deteriorada, se pueden relacionar todos estos aspectos y el deterioro selectivo de la arenisca, que es la cuestión que nos ocupa. Las microfotografías de las figuras 3 ( a y b) corresponden a planos paralelos a la superficie exterior de dos sillares deteriorados, situados en los muros norte y sur de la Catedral Vieja, a la altura del nivel primero. En ambas pueden verse las capas de arcilla y sólo en puntos concretos dejan al descubierto granos de arena. Imágenes semejantes a estas son las que muestran las figuras 3 ( c y d), pertenecen a planos, no paraleilas a la superficie exterior, de dos sillares de piedra no deteriorada, situados, uno en la parte baja de entrada a la Torre, y otro en el muro sur de la Catedral Vieja a la altura del nivel primero. Los planos paralelos al asiento de dos sillares de piedra deteriorada, en los muros norte y sur de la Catedral Vieja y a la altura del nivel primero, muestran microtextura granular, figuras 4 (a y b). Ésta es semejante a la que muestran los planos paralelos a la superficie exterior de sillares de piedra no deteriorada en los mismos muros, figuras 4 ( c y d). Comparaciones con imágenes obtenidas del resto de las muestras llevan a resultados semejantes.

Concluyendo, la microtextura laminar coincide en las superficies expuestas al exterior de las muestras deterioradas. La microtextura granular coincide en las superficies exteriores de las muestras no deterioradas. Los sillares no colocados a lecho tienen más probabilidad de ser deteriorados superficialmente. Consecuentemente, la anisotropía textural de las areniscas se ve reflejada en el deterioro selectivo que presentan en el edificio.

\section{VALORACIÓN DE LA ANISOTROPÍA TEXTURAL EN ARENISCAS DE CANTERA}

Las velocidades de las ondas longitudinales ultrasónicas, medidas en las tres direcciones de un bloque de piedra, permiten valorar su comportamiento anisotrópico. Zezza (12) da los valores de anisotropía total en diferentes tipos de piedras calculados por la fórmula;

$$
\Delta \mathrm{M} \%=100\left\{1-\left(2 \mathrm{VL}_{1} / \mathrm{VL}_{2}+\mathrm{VL}_{3}\right)\right\}
$$

$\mathrm{VL}_{1}, \mathrm{VL}_{2} \mathrm{y} \mathrm{VL}_{3}$ son los valores de las velocidades en las tres direcciones de fábrica.

Las medidas se hicieron en 36 muestras de cantera. Los resultados obtenidos después de aplicarlas a la fórmula dada, se representan de forma gráfica en la Fig. 5. case with this sandstone in the study mentioned above In such a case, there is a loss of cementing material, by which the stone is progressively turned into sand.

After comparing the SEM pictures of deteriorated stone samples with those of unaffected stone, all these aspects and the selective deterioration of the sandstone can be related, which is the purpose of this study. The microphotographs of figures $3(a$ and $b$ ) correspond to the planes parallel to the exterior surface of two deteriorated ashlars at the first level in the north and south wall of the Vieja Cathedral. The clay layers can be seen in both and sand grains are observed only at specific points. Figures 3(c and d) are similar pictures: they belong to planes - not parallel to the exterior surface -of two unaffected ashlars from the lower part of the entrance to the tower in one case and from the southern wall at the first level of the Vieja Cathedral. The planes parallel to the placing of two deteriorated ashlars in the north and south walls at the first level of the Vieja Cathedral have a granular texture: Figures 4( $a$ and $b$ ). This is similar to that of the planes parallel to the exterior surface of the unaffected ashlar in the same walls: Figures 4(c and d). The comparison with pictures of the remaining samples leads to similar results.

In conclusion, the surface areas exposed to the outside deteriorate more easily in the ashlars not placed in line with the stratum. Consequently, textural anisotropy in the sandstone is reflected by selective deterioration of the blocks in the building. The intensity of this effect depends on the greater or lesser degree of textural anisotropy of the stone.

\section{ESTIMATING TEXTURAL ANISOTROPY IN QUARRY SANDSTONE}

By measuring the speeds of longitudinal ultrasonic waves in the three directions of a block of stone it is possible to estimate its anisotropic behaviour. Zezza ${ }^{(22)}$ give the values of total anisotropy for different kinds of stone by using the formula:

$$
\Delta M \%=100\left\{1-\left(2 V L_{1} / V L_{2}+V L_{3}\right)\right\} .
$$

$V L_{1}, V L_{2}$ and $V L_{3}$ are the speed values of the three fabric directions.

The measurements were taken for 36 quarry samples. The results obtained after using the above formula are given graphically in Fig. 5. 
Estos resultados confirman la anisotropia textural, en mayor o menor grado, de las areniscas. Como muestra la gráfica, hay valores extremos, hasta del $20 \%$ de anisotropía total, pero los valores intermedios, entre 8 y $10 \%$, son los más frecuentes.

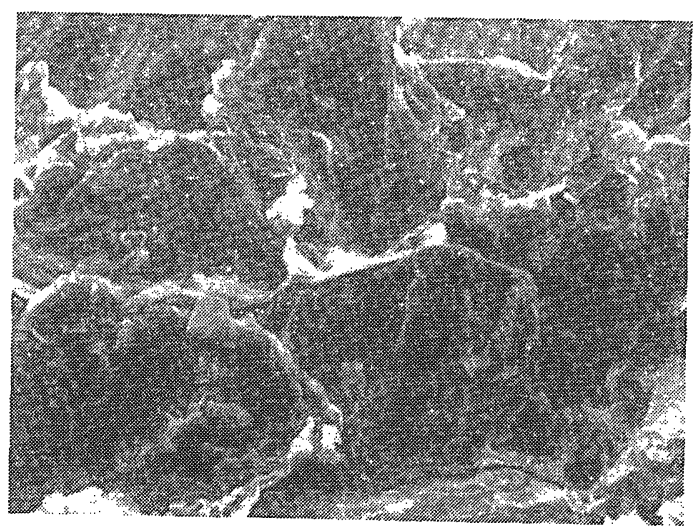

These results confirm the textural anisotropy of sandstone to a greater or lesser degree. The diagram shows that there are some extreme values - up to $20 \%$ of total anisotropy -, but the intermediate values between 8 and $10 \%$ - are the most frequent.

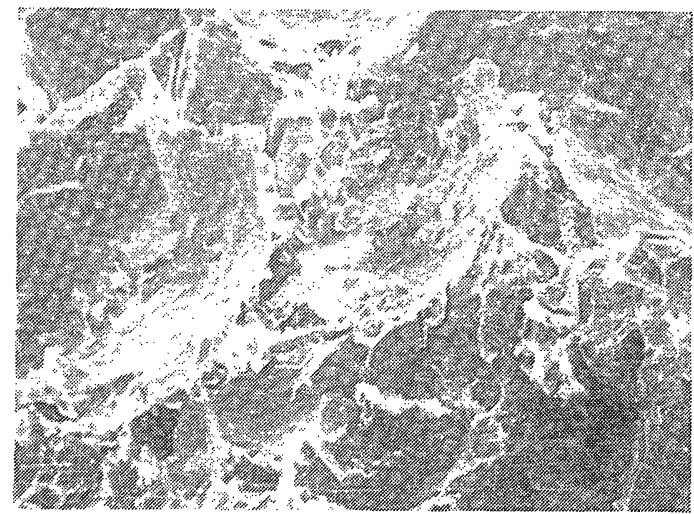

Fig. 2.- Imágenes del SEM en dos cortes de una muestra de arenisca: (a) granos de arena bordeados por arcillas, barra $=10 \mu \mathrm{m}$, (b) láminas de arcilla, barra $=10 \mu \mathrm{m}$.
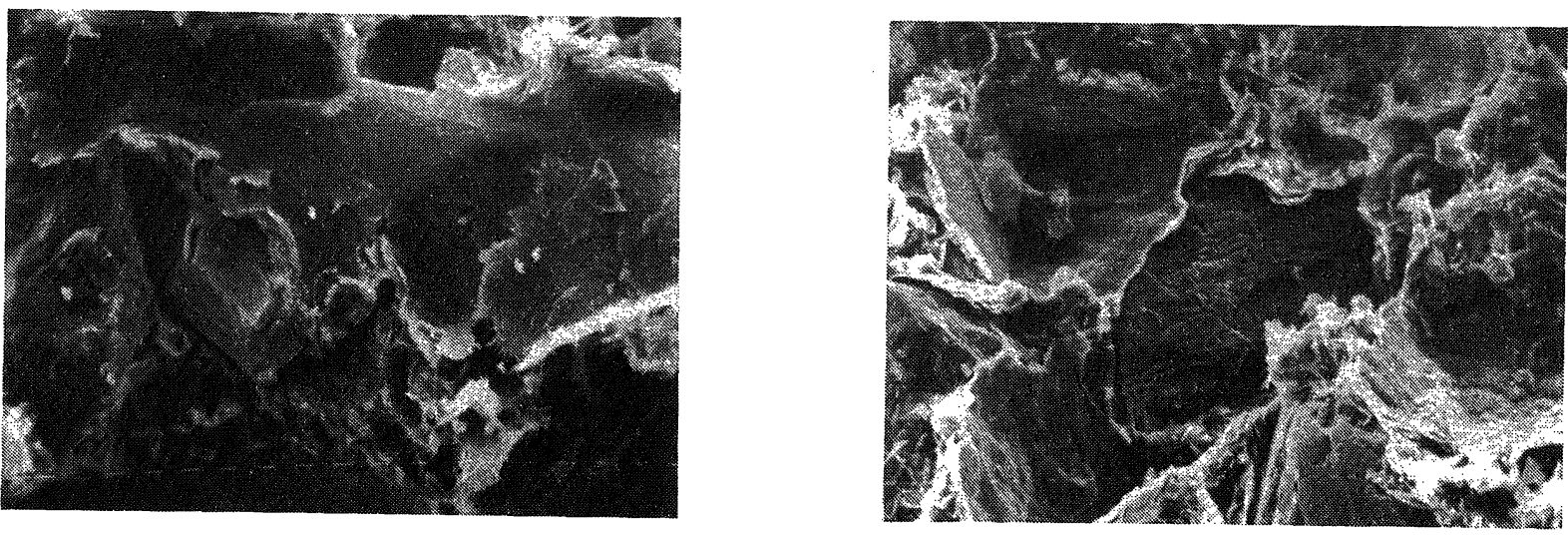

a
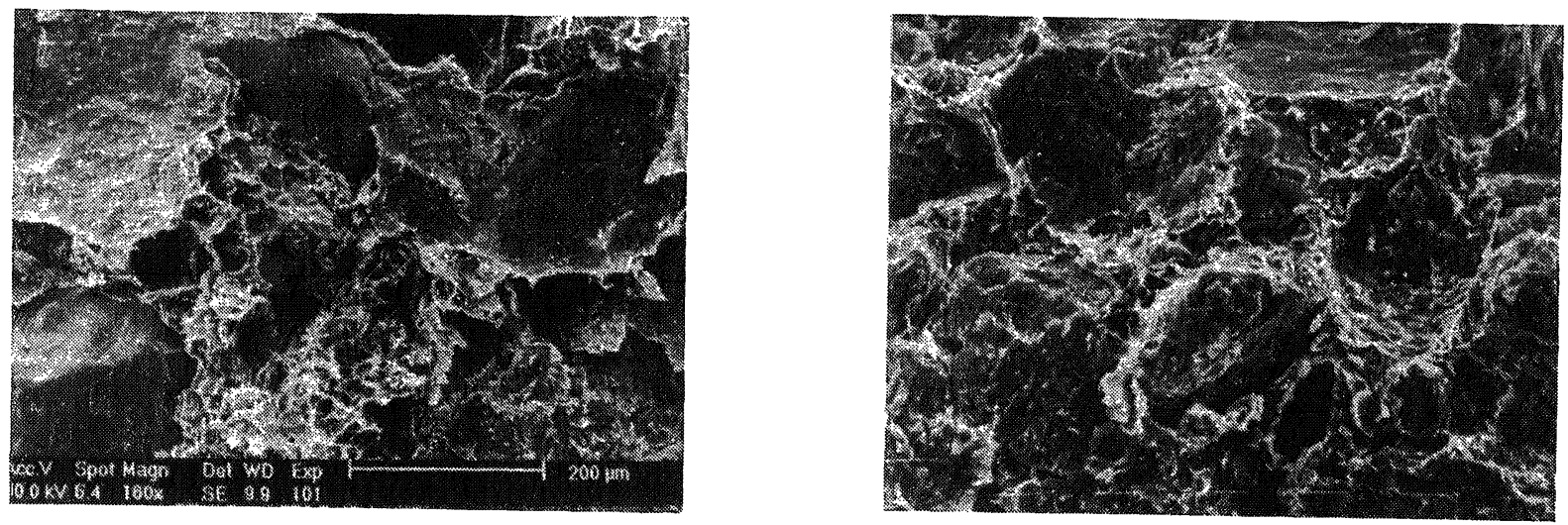

Fig.3.- Imágenes del SEM en dos muestras de arenisca. Microtextura laminar: (a) y (b) cortes en planos paralelos a la superficie exterior de dos sillares deteriorados, barra $=10 \mu \mathrm{m},(\mathrm{c})$ y $(\mathrm{d})$ cortes en planos no paralelos a la superficie exterior de dos sillares no deteriorados, barra $=200 \mu \mathrm{m}$ y $1 \mu \mathrm{m}$, respectivamente. 

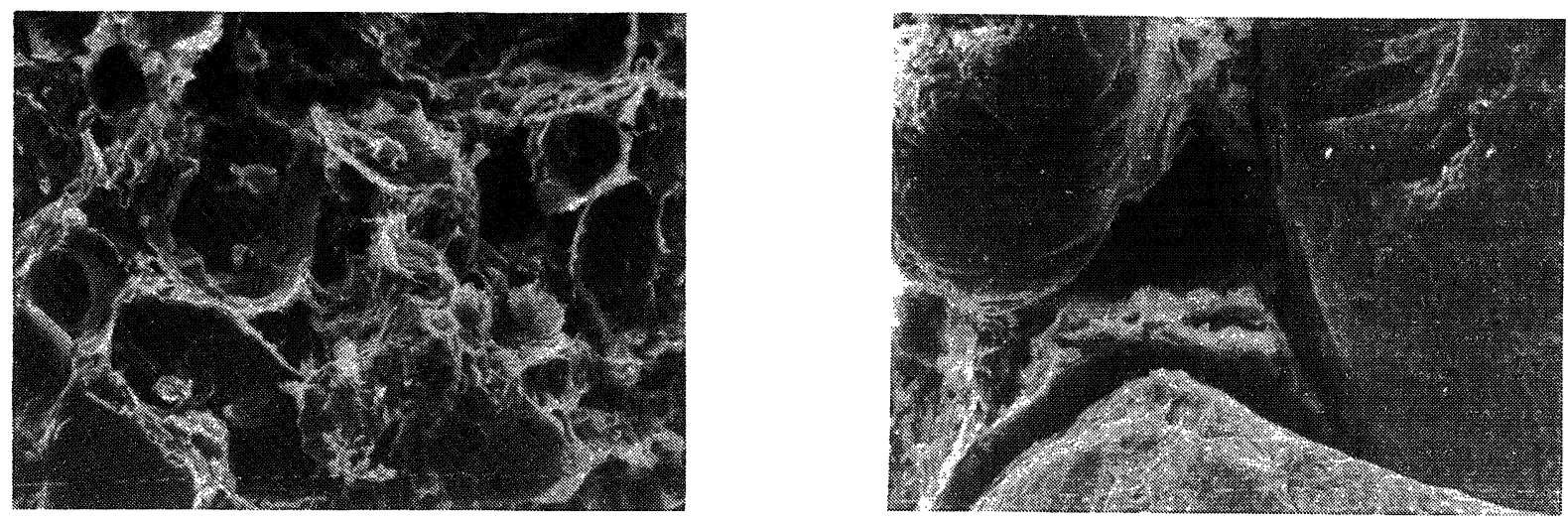

a
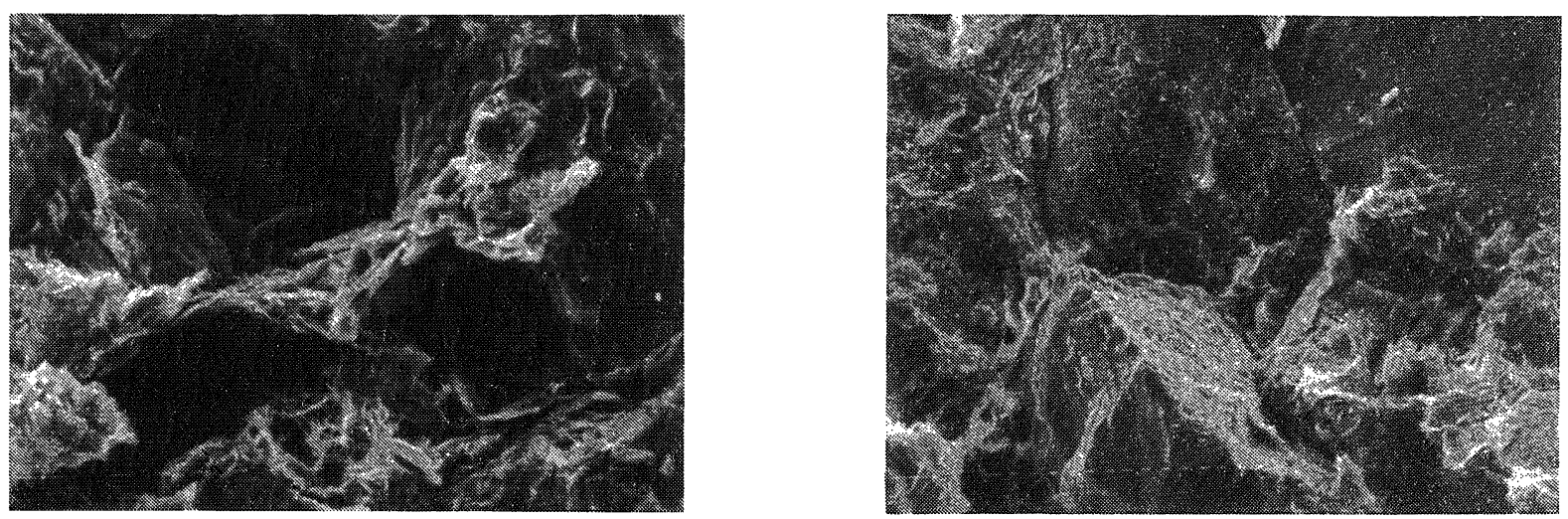

c

Fig.4.- Imágenes del SEM en dos muestras de arenisca. Microtextura granular: (a) y (b) cortes en planos paralelos a la base de dos sillares deteriorados, barra $=10 \mu \mathrm{m}$, (c) y (d) cortes en planos paralelos a la superficie exterior de dos sillares no deteriorados, barra $=10 \mu \mathrm{m}$.

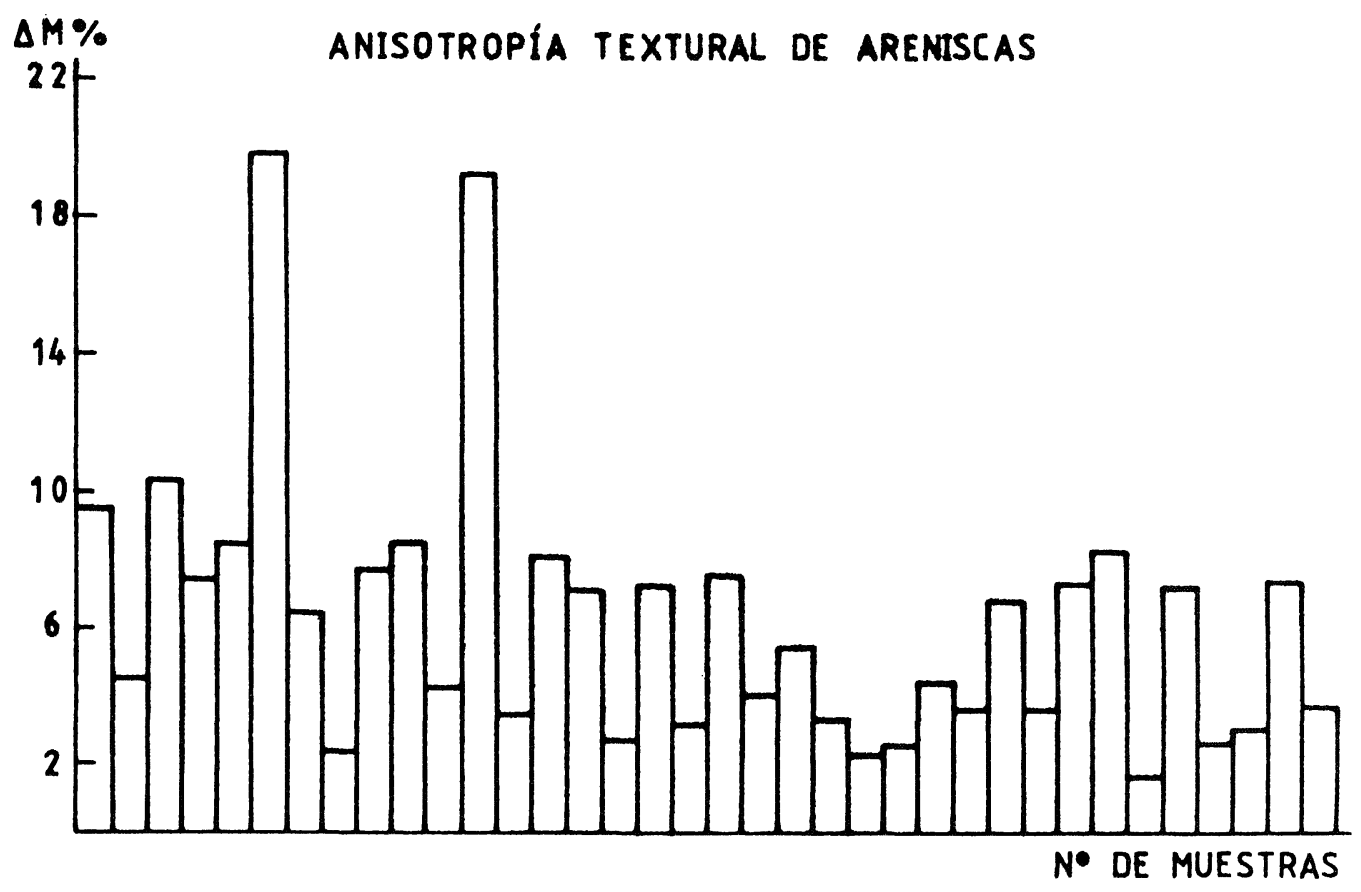

Fig.5.- Representación gráfica de los valores de anisotropía total en 36 areniscas de cantera comercial. 


\section{ENSAYOS ACELERADOS EN ARENISCAS DETERIORADAS Y NO DETERIORADAS}

Los ensayos consistieron en la repetición de ciclos de humedad y secado, cinco días de humedad y tres días de secado a temperatura ambiente, con diez probetas de la misma piedra que hemos mencionado, deterioradas y no deterioradas.

Las probetas de forma cilíndrica, $10 \mathrm{~cm}$ de diámetro y $2 \mathrm{~cm}$ de alto, se cortaron de la parte interna de cada testigo, de tal manera que las superficies, inferior y superior, fueran paralelas al plano expuesto al exterior en el edificio. Éstas se colocaron en la bandeja que contenía una disolución salina, quedando las bases en contacto con el líquido y las superficies superiores al aire (13). El resto de las superficies se protegieron para evitar la evaporación en esas zonas. Siguiendo el método empleado por Alcalde (14), todo el sistema se introdujo en un túnel de plástico donde se estableció corriente de aire.

\section{ACCELERATED TESTS IN DETERIORATED AND UNAFFECTED SANDSTONE}

The tests consisted of the repetition of humid and drying cycles, ie, five days humidity and three days drying at room temperature, with ten test samples of the stone described in a state of deterioration or not.

The test samples were round with a diameter of $10 \mathrm{~cm}$ and a height of $2 \mathrm{~cm}$. They were cut from the inside of each original sample in such a fasion that the bottom and top surface ares were parallel to the plane exposed to the outside in the building. The test samples were placed on a tray with a saline solution, the bottom end in the liquid and the top end in the air (13). The remaining surface was protected to prevent evaporation there. Following the method used by Alcalde (14), the whole system was introduced in a plastic tunnel, where an air current was created.

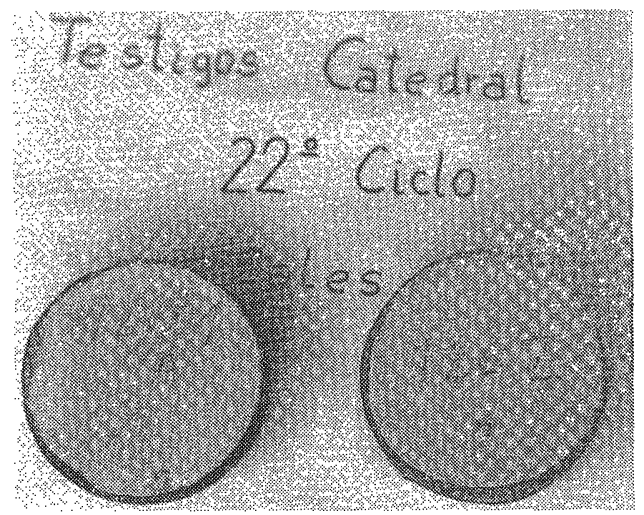

Fig.6.- Probetas de dos muestras, con la misma situación en el edificio. Formación de sales sobre la superficie de la muestra deteriorada y sin cambio en la muestra no deteriorada, después de 22 ciclos de humedad-secado.
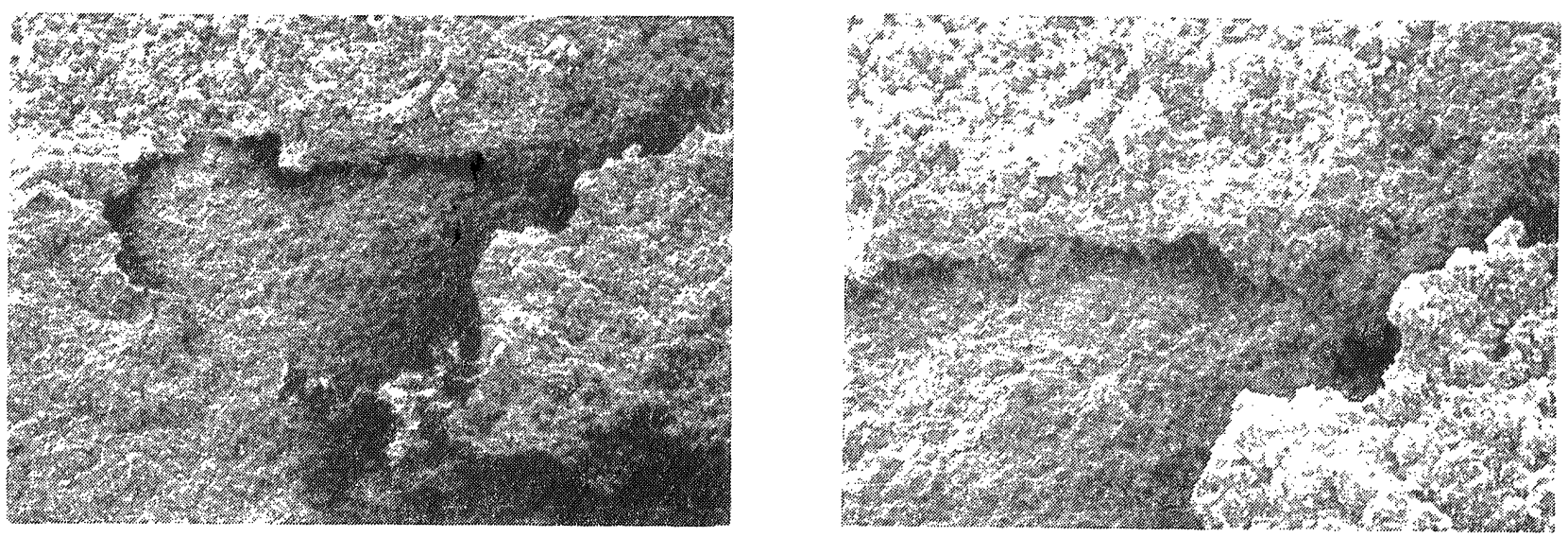

Fig.7.- Imágenes del SEM de las sales cristalizadas sobre la superficie de la muestra deteriorada, barra $=1 \mu \mathrm{m}$. 
Después de 22 ciclos, se observó la formación de costras blancas sobre la superficie superior de las probetas de piedras deterioradas. Las superficies de las piedras no deterioradas no presentaron cambios perceptibles, sólo hubo indicios sobre alguna de éstas, lo que nos hace pensar en un proceso de cristalización de sales más lento cuando la piedra en el edificio ha resistido sin deterioro. La Fig. 6, muestra el aspecto que presentaban dos probetas después de haber pasado 22 ciclos de humedad-secado: la de la parte izquierda es una piedra ya deteriorada, y la de la parte derecha es sin deteriorar; ambas corresponden a la fachada norte de la Catedral Vieja.

Las imágenes en SEM de la Fig. 7 son de las mismas costras. Los microanálisis químicos, excluyendo los de elementos ligeros realizados por EDAX, dan resultados de $\mathrm{S}$ y $\mathrm{Ca}$; se trata por tanto de cristalizaciones de sulfato de calcio. Cuando estudiamos las formas de alteración de las areniscas en las Catedrales (1), encontramos cristalizaciones de sulfato de calcio en las piedras deterioradas, nunca en la proporción que resulta en un tratamiento tan agresivo como es el de laboratorio.

Las disoluciones acuosas ascienden por capilaridad a través de la piedra hasta la superficie, cristalizando cuando las condiciones son las adecuadas. Si la situación exterior es la misma para todo el ensayo, ha de ser la disposición de los planos en la estructura interna de la piedra, la que limite la velocidad de ascensión del líquido hasta la superficie de evaporación. Variaciones en la porosidad, o en el tamaño de los poros de estas piedras, explicarían estos comportamientos diferentes. Sin embargo, no existe tal distinción, y menos cuando se trata de piedras, deteriorada y no deteriorada, con situaciones idénticas en el edificio, tal como se deducía de los resultados obtenidos por medio de la técnica de intrusión de mercurio presentados en el trabajo citado (1).

Las disoluciones acuosas han cristalizado sobre las superficies, paralelas al plano expuesto al exterior en el edificio, de las piedras deterioradas. Como se deduce de todo este estudio, tales superficies tienen microtextura predominantemente arcillosa.

Estos resultados confirman que el deterioro superficial de la arenisca en un edifício está relacionada con la orientación del sillar o bloque de piedra en el mismo, especialmente si se trata de areniscas con valores de anisotropía textural altos. Dato importante cuando es obligado hacer reemplazamientos pétreos en la restauración de monumentos
After 22 cycles, it was found that white crusts formed on the top surface of the test samples of the deteriorated stone. There were no visible changes on the surface of the unaffected stone. Only some traces were observed on some of them, which may point to the possibility of a slower salt crystallization process when the stone has remained unaffected in the building. The photograph of Fig. 6 shows the appearance of two test samples after 22 humidity-drying cycles. That on the left hand is an already deteriorated stone, while that on the right is unaffected. Both are from the northern façade of the Vieja Cathedral.

The SEM pictures of Fig. 7 are of the same crusts. Excluding those of light elements, the chemical microanalysis by EDAX produces $S$ and $C a$. It is therefore a crystallization of calcium sulphate. When the forms of weatheing in the sandstone of the Cathedrals (1) were studied, calcium sulphate crystallizations were found in the deteriorated stones, but never in the proportion resulting from as aggressive a treatment as that in the laboratory.

Salts crystallize when, under appropriate conditions, water solutions travel through the stone to the surface by means of capillarity. If the exterior situation is the same throughout the test, the internal structure of the stone limits the speed of the liquid in reaching the evaporation surface. Such varying behaviour is explained by the variations in porosity or in the size of the pores of the stone. There is no such distinction, however, and even less so in deteriorated or unaffected stones with identical positions in the building. This was also deduced from the results obtained by means of the mercury intrusion technique described in the study mentioned above (1).

The water solutions have come to crystallize on the most clayey surface areas, a conclusion that can be deduced from the study as a whole.

It must again be emphasized that the position given to the block of stone in the building is of importance for the durability of the stone, especially when the sandstone has a high degree of textural anisotropy. This is also important when it comes to replacing stone in the course of restorations. 


\section{BIBLIOGRAFÍA}

(1) MARTÍN PATINO, Ma T., MADRUGA, F., SAAVEDRA, J., (1992): Characterization of the Sandstone of the Salamanca Cathedrals. Forms of Weathering., 7th International Congress on Deterioration and Conservation of Stone, Lisbon, Portugal, Vol. I, 315-324.

(2) MARTÍN PATINO, Ma T., MADRUGA, F., SAAVEDRA, J., (1994): Análisis del tamaño de partículas en areniscas de las Catedrales de Salamanca. Independencia entre granulometría y deterioro. Materiales de Construcción, $n^{\circ} 233$, Vol. 44, 5-21.

(3) ARRIBAS, A., POLO, V., JIMÉNEZ, E., (1984): La "enfermedad de la piedra" en la arenisca de Villamayor. En Estudio sobre la alteración y tratamiento de la piedra de Villamayor.Ed.Caja de Ahorros y Monte de Piedad de Salamanca, 15-169.

(4) HERNÁNDEZ, J., CARABIAS, R., ALONSO, A., JIMÉNEZ, O., SÁNCHEZ, E., CORROCHANO, J., MARTÍN POZAS, J., (1984): Alteraciones de la arenisca de Villamayor; causas y soluciones. En Estudio sobre la alteración y tratamiento de la piedra de Villamayor. Ed. Caja de Ahorros y Monte de Piedad de Salamanca. 177-311.

(5) ORDAZ, J., ESBERT, R.M., MONTOTO, M., DE CASO, F., ALONSO, F. J., (1984): Estado de alteración y alteración futura de la piedra de Villamayor de los monumentos salmantinos; interpretación petrográfica. En Estudio sobre alteración y tratamiento de la piedra de Villamayor. Ed. Caja de Ahorros y Monte de Piedad de Salamanca, 483-563.

(6) OTEO MAZO, C., CUEVA, J., GARCÍA MARCOS, R., NICOLÁS, M., (1984): Potencial de alterabilidad de la piedra de Villamayor. En Estudio sobre la alteración y tratamiento de la piedra de Villamayor. Ed. Caja de Ahorros y Monte de Piedad de Salamanca, 321-415.

(7) VICENTE, M.A., SÁNCHEZ, M., LOMBARDÍA, F., VICENTE, I., SAAVEDRA, J., BRUFAU, A., (1984): Contribución al estudio de las causas de alteración de las piedras de Villamayor en edificios salmantinos y de los posibles métodos de corrección. En Estudio sobre la alteración y tratamiento de la piedra de Villamayor. Ed. Caja de Ahorros y Monte de Piedad de Salamanca. 429-471.

(8) VICENTE, M.A., BRUFAU, A., (1986): Weathering of the Villamayor arcosic sandstone used in building under a continental semiarid climate. Applied Clay Science, 1, 265-270.

(9) BLANCO, J.A., (1989): Dinámica del proceso de alteración ambiental de la piedra de Villamayor. Geogaceta, 6, 32-35.

(10) MEGIAS, J.M., MADRUGA, F., FERNÁNDEZ CALVO, C., (1989): La arenisca de Villamayor; influencia de la humedad en su resistencia. Geogaceta, 6, 39-40.

(11) AMOROSO, G.G., FASSINA, V., (1983): Stone decay and conservation. Elsevier.

(12) ZEZZA, U., (1990): Physical-mechanical properties of quarry and building stones. University of Pavia (Italy), 1-21.

(13) MADRUGA, F., SAAVEDRA, J., MARTÍN PATINO, $M^{\mathrm{a}} \mathrm{T}$., (1994): Eflorescencias y costras sobre areniscas de Villamayor. Ensayos de laboratorio. Materiales de Construcción, Vol. 44, n 234, 39-44.

(14) ALCALDE, M.,(1988): Sintomatología de alteraciones de las catedrales de Sevilla, Cádiz y Almería. Tesis Doctoral, Universidad de Sevilla. 